\title{
Central Venous Oxygenation for Mixed Venous Oxygen Saturation
}

\author{
Naresh Kumar Agarwal ${ }^{1} \quad$ Arun Subramanian ${ }^{1}$ \\ ${ }^{1}$ Department of Cardiac Anesthesiology, Manipal Hospitals, \\ New Delhi, India
}

\begin{abstract}
Address for correspondence Arun Subramanian, MD, MNAMS, DM, Department of Cardiac Anesthesiology, Manipal Hospitals, Dwarka Sector-6, New Delhi 110075, India (e-mail: aruncardiac@live.com).
\end{abstract}

\author{
Abstract \\ Keywords \\ - hypoxia \\ - mixed venous oxygen \\ saturation \\ - central venous oxygen \\ saturation \\ - cardiac surgery \\ - shock \\ - oxygen demand \\ - oxygen supply
}

Venous oxygen saturation has been traditionally used as a marker for tissue hypoxia. A wide range of factors can affect it. Literature abounds with articles on the use of the same in decision making and clinical management of patients in shock. Likewise, the application of venous saturation in patients undergoing cardiac and noncardiac surgery has been demonstrated. The controversy as to whether superior vena cava oxygen saturation can replace the traditional mixed venous oxygen saturation is never ending. Irrespective of the body of evidence, it is recommended that clinical decision should not be based on a single value, and a range of values needs to be incorporated to differentiate a critically ill from a noncritically ill patient.

\section{Introduction}

Morbidity and mortality after major cardiac surgeries are serious issues to any health care system. ${ }^{1}$ Even for the patients who leave the hospital, postoperative complications are an important determinant of long-term survival. ${ }^{2}$ Thus it seems imperative that we devise strategies that can help us in identifying these patients quite early in their clinical course, so that we can implement measures to improve the outcome of such patients.

One of the major determinants of postoperative outcome is the cardiorespiratory function of the patient. It has been demonstrated that global tissue hypoxia is associated with poor results after major surgeries., ${ }^{3,4}$ This can be reduced by optimal volume replacement and inotropes., ${ }^{5,6}$ Despite this, it is important that we recognize the symptoms of tissue hypoxia in advance, so that we may be well equipped to handle the situation. Mixed venous oxygen saturation $\left(\mathrm{SvO}_{2}\right)$ and central venous oxygen saturation $\left(\mathrm{ScvO}_{2}\right)$ have been found to be surrogate markers of tissue hypoxia. ${ }^{7.8}$ Clinicians must be aware of the measurement, advantages, and pitfalls of the above markers, so that they can be applied safely and effectively. The aim of this article is to describe the physiology of $\mathrm{SvO}_{2}$ and $\mathrm{ScvO}_{2}$, elucidate the findings of pertinent clinical investigations, and debate on the equality or interchangeability of $\mathrm{SvO}_{2}$ and $\mathrm{ScvO}_{2}$. We searched PubMed, Google Scholar, and Cochrane databases with the following keywords: venous saturation, venous oximetry, tissue hypoxia, and cardiac surgery.

\section{Background Physiology}

It is mandatory we understand the physiology of venous saturation before we apply it in the bedside management of the patient. What do $\mathrm{SvO}_{2}$ and $\mathrm{ScvO}_{2}$ represent? They represent the hemoglobin saturation of the blood in the pulmonary artery and superior vena cava, respectively. What are the factors influencing the saturation of the venous blood? The oxygen saturation of the venous blood is dependent on the hemoglobin levels $(\mathrm{Hb})$, arterial oxygen saturation $\left(\mathrm{SaO}_{2}\right)$, cardiac output (CO), and tissue oxygen consumption $\left(\mathrm{VO}_{2}\right)$. Therefore, as per the Fick principle, ${ }^{9} \mathrm{SvO}_{2}$ is described by the following formula:

$$
\begin{gathered}
\mathrm{SaO}_{2}-\mathrm{VO}_{2} \\
\mathrm{SvO}_{2}=---------- \\
\mathrm{CO} \times \mathrm{Hb} \times 1.34
\end{gathered}
$$

The normal range of venous saturation is usually 65 to $75 \%$ in healthy individuals; however, few studies exist, which showcase the normal values. ${ }^{10}$ The earliest study,

Copyright @2018 Official Publication of The Simulation Society (TSS), accredited by International Society of Cardiovascular Ultrasound (ISCU).
License terms

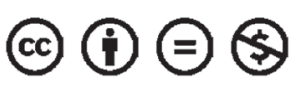


which provided an in-depth description of $\mathrm{Hb}$ saturation in the venous system of healthy patients, demonstrated mean values of $76.8 \%$ in the superior vena cava and $78.4 \%$ in the pulmonary arteries. It is usually recommended to target an $\mathrm{ScvO}_{2}>70 \%$ and an $\mathrm{SvO}_{2}>65 \%$ in all subset of patients. It is also recommended to follow a trend in the values rather than initiating therapy based on a single value.

How do we measure venous oxygen saturation? Although the measurement of $\mathrm{ScvO}_{2}$ and $\mathrm{SvO}_{2}$ was initiated in the catheterization laboratory in 1929, it was the landmark paper by Swann et al, ${ }^{11}$ which described the floatation of the pulmonary artery catheter that facilitated the routine measurement of $\mathrm{SvO}_{2}$. Nowadays, estimation of saturation can be done either intermittently by blood sampling or continuously through the use of a spectrophotometric catheter. ${ }^{12,13}$

A host of physiologic, pathologic, and therapeutic factors influence the venous saturation during the perioperative

Table 1 Factors influencing the venous oxygen saturation in the perioperative period

\section{A. Decreased venous oxygen saturation}

1. Decreased oxygen delivery-anemia, hypoxia, hypovolemia, cardiac failure.

2. Increased oxygen consumption-pain, fever, shivering, sepsis.

\section{B. Increased venous oxygen saturation}

1. Increased oxygen delivery-inotropes, fluids, blood and blood products, supplemental oxygen.

2. Decreased oxygen consumption-sedation, analgesia, hypothermia, paralysis. period (-Table 1). Recognizing the etiology is necessary for the safe use of venous saturation as a therapeutic goal.

\section{Central versus Mixed Venous Oxygen Saturation}

The interchangeability or equality of $\mathrm{ScvO}_{2}$ and $\mathrm{SvO}_{2}$ has been a matter of great debate over many years in pediatric and adult population ${ }^{14-24}$ (-Table 2 ). In clinical practice, the simplicity of $\mathrm{ScvO}_{2}$ measurement has always been a factor for clinicians to equate the two variables. The determinants of both the variables are nearly similar. Despite this, it has to be understood that they cannot always be used interchangeably. This becomes more valid in case of critically ill patients. The differences in the blood flow distribution and oxygen consumption by the vital organs such as the brain and heart in shock states explains this discrepancy. ${ }^{25}$

Normally, the difference between $\mathrm{ScvO}_{2}$ and $\mathrm{SvO}_{2}$ is around $5 \%$, with the $\mathrm{ScvO}_{2}$ lagging behind $\mathrm{SvO}_{2}$. This is due to the relatively higher $\mathrm{VO}_{2}$ of the brain and the higher oxygen content of the inferior vena cava. ${ }^{26}$ However, in shock states the redistribution of blood to the upper extremities leads to a reversal in the relationship. Hence, in critically ill patients, the $\mathrm{ScvO}_{2}$ overtakes $\mathrm{SvO}_{2}$ by 15 to $20 \% .{ }^{27}$ Therefore, measuring the $\mathrm{ScvO}_{2}$ in such cases may provide us a false sense of security that everything is quite rosy. This may also be expanded to the perioperative period although with mixed results. The general consensus during surgery is that while the two may a have a good positive correlation, they agree with each other only when measured as a trend and not as absolute values. ${ }^{28}$ To conclude, clinicians must be very prudent in surmising the value of one variable from the other.

Table 2 Studies correlating $\mathrm{SvO}_{2}$ with $\mathrm{ScvO}_{2}$

\begin{tabular}{|c|c|c|c|}
\hline Study & Design and setting & Result & Inference \\
\hline Alshaer et al ${ }^{14}$ & $\begin{array}{l}n=34 \text {; coronary artery } \\
\text { bypass grafting; OR and ICU; } \\
12 \text { measurements per patient }\end{array}$ & $\begin{array}{l}\mathrm{ScvO}_{2} \text { higher than } \mathrm{SvO}_{2} \text { all through } \\
\text { the study } \\
\text { Mean of difference highest post ICU } \\
\text { admission }(6.3 \text { and } 4.6 ; p<0.05)\end{array}$ & $\begin{array}{l}\mathrm{ScvO}_{2} \text { is equivalent to } \mathrm{SvO}_{2} \text { in } \\
\text { the course of clinical decisions as } \\
\text { long as absolute values are not } \\
\text { required, but not interchangeable }\end{array}$ \\
\hline Ali et $\mathrm{al}^{15}$ & $\begin{array}{l}n=40 ; 240 \text { samples; } \\
\text { pediatric cardiac surgery, OR }\end{array}$ & $\begin{array}{l}\text { Wide limits of agreements between } \\
\mathrm{ScvO}_{2} \text { and } \mathrm{SvO}_{2}(14.2 \text { to }-15.3)\end{array}$ & $\begin{array}{l}\mathrm{SvO}_{2} \text { and } \mathrm{ScvO}_{2} \text { are not inter- } \\
\text { changeable in pediatric open- } \\
\text { heart surgeries }\end{array}$ \\
\hline Kopterides et al ${ }^{16}$ & $n=37 ;$ septic shock & $\begin{array}{l}\text { Mean } \mathrm{SvO}_{2} \text { below mean } \mathrm{ScvO}_{2} \text {; } \\
\text { mean bias }-8.5 \% \\
95 \% \text { limits of agreement }-20.2 \text { to } \\
3.3 \% \text {; this resulted in higher } \mathrm{VO}_{2} \\
\text { values }\end{array}$ & $\begin{array}{l}\mathrm{ScvO}_{2} \text { and } \mathrm{SvO}_{2} \text { not equivalent in } \\
\mathrm{ICU} \text { patients with septic shock; } \\
\text { substitution of } \mathrm{ScvO}_{2} \text { for } \mathrm{SvO}_{2} \\
\text { in calculation of } \mathrm{VO}_{2} \text { resulted in } \\
\text { unacceptably large errors }\end{array}$ \\
\hline $\begin{array}{l}\text { El-Sherbeny and } \\
\text { Belahith }^{17}\end{array}$ & $\begin{array}{l}n=56 ; 300 \text { measurements; } \\
\text { postcardiac surgery; ICU }\end{array}$ & $\begin{array}{l}\text { Correlation between } \mathrm{SvO}_{2} \text { and } \mathrm{ScvO}_{2} \\
\text { was } r=0.79(p<0.001) . \text { Mean bias } \\
\text { between } \mathrm{SvO}_{2} \text { and } \mathrm{ScvO}_{2} \text { was } 3.8 \% \text {, } \\
\text { and } 95 \% \text { limits of agreement were } \\
(+15.8 \text { to }-8.2 \%)\end{array}$ & $\begin{array}{l}\text { Poor agreement between } \mathrm{ScvO}_{2} \\
\text { and } \mathrm{SvO}_{2} \text { in patients following } \\
\text { cardiac surgery }\end{array}$ \\
\hline el-Masry et al ${ }^{18}$ & $\begin{array}{l}n=50 \text {; liver transplantation; } \\
450 \text { measurements; pre-, } \\
\text { during, and posttransplant }\end{array}$ & $\begin{array}{l}\text { Strong positive correlation for } \mathrm{SvO}_{2} \\
\text { with } \mathrm{ScvO}_{2}(r=0.98 \text { and } 0.87 \text { at pre- } \\
\text { and posttransplant, respectively) } \\
95 \% \text { limit of agreement ranged } \\
\text { from }-1.94 \text { to } 2.7 \text { and }-6.07 \text { to } \\
1.07 \text { at pre- and posttransplant, } \\
\text { respectively }\end{array}$ & $\begin{array}{l}\text { Minimal bias between } \mathrm{ScvO}_{2} \text { and } \\
\mathrm{SvO}_{2} \text {; hence it can be interchanged }\end{array}$ \\
\hline
\end{tabular}


Table 2 Studies correlating $\mathrm{SvO}_{2}$ with $\mathrm{ScvO}_{2}$

\begin{tabular}{|c|c|c|c|}
\hline Study & Design and setting & Result & Inference \\
\hline Romagnoli et al ${ }^{19}$ & $\begin{array}{l}n=18 \text {; cardiogenic shock } \\
\text { undergoing cardiac surgery; } \\
\text { ICU; } 72 \text { paired samples }\end{array}$ & $\begin{array}{l}\text { Bias of difference } 6.82 \% \\
95 \% \text { limits of agreement }-3.7 \text { to } \\
17.3 \% \text { between } \mathrm{ScvO}_{2} \text { and } \mathrm{SvO}_{2}\end{array}$ & $\begin{array}{l}\text { Poor agreement between } \mathrm{ScvO}_{2} \\
\text { and } \mathrm{SvO}_{2} \text { in patients with car- } \\
\text { diogenic shock following cardiac } \\
\text { surgery }\end{array}$ \\
\hline Pérez et $a^{20}$ & $\begin{array}{l}n=30 \text { ( } 18 \text { catecholamine } \\
\text { refractory shock and } 12 \\
\text { postoperative); critically ill } \\
\text { pediatric patients; ICU }\end{array}$ & $\begin{array}{l}\text { Bias of difference was } 2 \% \text { and } 95 \% \\
\text { limits of agreement }-6.9 \text { to } 10.9 \% \\
\text { between } \mathrm{ScvO}_{2} \text { and } \mathrm{SvO}_{2}\end{array}$ & $\begin{array}{l}\mathrm{ScvO}_{2} \text { and } \mathrm{SvO}_{2} \text { are closely related } \\
\text { and interchangeable in critically ill } \\
\text { pediatric population }\end{array}$ \\
\hline Yazigi et al ${ }^{21}$ & $\begin{array}{l}n=60 ; \text { postcoronary artery } \\
\text { surgery; pre- (T0) and } \\
\text { post-normalization (T1) of } \\
\text { filling pressures and cardiac } \\
\text { index }\end{array}$ & $\begin{array}{l}\text { Bias between } \mathrm{SvO}_{2} \text { and } \mathrm{ScvO}_{2} \text { was } \\
-0.6 \% \text { (T0) and }-0.8 \%(\mathrm{~T} 1) \text {. Limits of } \\
\text { agreement were from } 19.2 \text { to } 18 \% \\
\text { (T0) and from } 15.6 \text { to } 14 \% \text { (T1), and } \\
\text { correlation coefficient was } 0.463 \\
\text { (T0) and } 0.72 \text { (T1) }\end{array}$ & $\begin{array}{l}\text { Disagreement between } \mathrm{ScvO}_{2} \text { and } \\
\mathrm{SvO}_{2} ; \mathrm{ScvO}_{2} \text { not an alternative for } \\
\mathrm{SvO}_{2}\end{array}$ \\
\hline Aggarwal et al 22 & $\begin{array}{l}n=20 ; \text { open-heart surgery; } \\
200 \text { measurements; OR }\end{array}$ & $\begin{array}{l}\text { Strong correlation between } \mathrm{SvO}_{2} \\
\text { and } \mathrm{ScvO}_{2} \\
\text { Regression coefficient and intraclass } \\
\text { correlation were } 0.99 \text { and } 0.91 \text {, } \\
\text { respectively }\end{array}$ & $\begin{array}{l}\mathrm{ScvO}_{2} \text { is a reliable marker for } \mathrm{SvO}_{2} \\
\text { can be interchanged }\end{array}$ \\
\hline Lorentzen et al ${ }^{23}$ & $\begin{array}{l}n=20 ; \text { elective cardiac } \\
\text { surgery; ICU }\end{array}$ & $\begin{array}{l}\text { Bias of difference between } \mathrm{ScvO}_{2} \\
\text { and } \mathrm{SvO}_{2} \text { was } 6.4 \text { in aortic valve } \\
\text { surgeries and } 0.6 \text { in coronary artery } \\
\text { bypass grafting }\end{array}$ & $\begin{array}{l}\mathrm{ScvO}_{2} \text { and } \mathrm{SvO}_{2} \text { are not } \\
\text { interchangeable in aortic } \\
\text { valve surgeries. They can be } \\
\text { interchanged, though there is no } \\
\text { complete accuracy in coronary } \\
\text { artery bypass grafting }\end{array}$ \\
\hline Redlin et $\mathrm{al}^{24}$ & $\begin{array}{l}n=20 ; \text { pediatric cardiac } \\
\text { surgery; OR; samples from } \\
\text { superior and inferior vena } \\
\text { cava, mixed venous samples } \\
\text { from cardiopulmonary bypass }\end{array}$ & $\begin{array}{l}\text { Linear correlation between inferior } \\
\text { vena cava and mixed venous } \\
\text { samples, no correlation between } \\
\text { superior vena cava and mixed } \\
\text { venous samples }\end{array}$ & $\mathrm{ScvO}_{2}$ poorly reflects $\mathrm{SvO}_{2}$ \\
\hline
\end{tabular}

Abbreviations: $\mathrm{DO}_{2}$, oxygen delivery; ICU, intensive care unit; OR, operating room; $\mathrm{ScvO}_{2}$, central venous oxygen saturation; $\mathrm{SvO}_{2}$, mixed venous oxygen saturation; $\mathrm{VO}_{2}$, oxygen consumption.

\section{Conclusion}

The debate as to whether $\mathrm{ScvO}_{2}$ and $\mathrm{SvO}_{2}$ are interchangeable is never ending. Although it has generally been agreed that in critically ill patients they must be assessed individually, the same may or may not be applicable to a patient undergoing surgery. We must focus on well-defined population and use these variables with knowledge and discretion. In clinical practice, venous oxygen saturations should always be used in combination with vital signs and other relevant endpoints to tailor therapy. Finally, it needs not be stressed that a trend in the saturation monitoring is always preferred to a solitary value.

\section{Conflict of Interests}

None.

\section{Acknowledgments}

None.

\section{References}

1 Pearse RM, Harrison DA, James P, et al. Identification and characterisation of the high-risk surgical population in the United Kingdom. Crit Care 2006;10(3):R81

2 Khuri SF, Henderson WG, DePalma RG, Mosca C, Healey NA, Kumbhani DJ; Participants in the VA National Surgical Quality Improvement Program. Determinants of long-term survival after major surgery and the adverse effect of postoperative complications. Ann Surg 2005;242(3):326-341, discussion 341-343

3 Murkin JM, Arango M. Near-infrared spectroscopy as an index of brain and tissue oxygenation. $\mathrm{Br} \mathrm{J}$ Anaesth 2009;103(Suppl 1):i3-i13

4 Jhanji S, Lee C, Watson D, Hinds C, Pearse RM. Microvascular flow and tissue oxygenation after major abdominal surgery: association with post-operative complications. Intensive Care Med 2009;35(4):671-677

5 Pearse R, Dawson D, Fawcett J, Rhodes A, Grounds RM, Bennett ED. Early goal-directed therapy after major surgery reduces complications and duration of hospital stay. A randomised, controlled trial [ISRCTN38797445]. Crit Care 2005;9(6):R687-R693

6 Wilson J, Woods I, Fawcett J, et al. Reducing the risk of major elective surgery: randomised controlled trial of preoperative optimisation of oxygen delivery. BMJ 1999;318(7191):1099-1103

7 Perz S, Uhlig T, Kohl M, et al. Low and "supranormal" central venous oxygen saturation and markers of tissue hypoxia in cardiac surgery patients: a prospective observational study. Intensive Care Med 2011;37(1):52-59

8 Marx G, Reinhart K. Venous oximetry. Curr Opin Crit Care 2006;12(3):263-268

9 Fick A. Ueber die Messung des Blutquantums in den Herzventrikeln. Verhandl Physik Med Gesellschafft Wurzburg 1870;2:16-28 
10 Nelson LD. Continuous venous oximetry in surgical patients. Ann Surg 1986;203(3):329-333

11 Swan HJ, Ganz W, Forrester J, Marcus H, Diamond G, Chonette D. Catheterization of the heart in man with use of a flow-directed balloon-tipped catheter. N Engl J Med 1970;283(9):447-451

12 Waller JL, Kaplan JA, Bauman DI, Craver JM. Clinical evaluation of a new fiberoptic catheter oximeter during cardiac surgery. Anesth Analg 1982;61(8):676-679

13 Baulig W, Dullenkopf A, Kobler A, Baulig B, Roth HR, Schmid ER. Accuracy of continuous central venous oxygen saturation monitoring in patients undergoing cardiac surgery. J Clin Monit Comput 2008;22(3):183-188

14 Alshaer A, Abdel-Meguid ME, Ibraheim O, et al. Mixed venous versus central venous oxygen saturation in patients undergoing on pump beating coronary artery bypass grafting. Saudi J Anaesth 2010;4(2):63-67

15 Ali MS, Abd-Elshafy SK, Abd Allah EM, Ghoneim AF. Can venous saturations from the central line and the venous side of the heart-lung machine be interchangeable with mixed venous saturation from the pulmonary artery in children undergoing open-heart surgery? Egypt J Cardiothroac Anesth 2017; $11: 48-52$

16 Kopterides P, Bonovas S, Mavrou I, Kostadima E, Zakynthinos E, Armaganidis A. Venous oxygen saturation and lactate gradient from superior vena cava to pulmonary artery in patients with septic shock. Shock 2009;31(6):561-567

17 El-Sherbeny A, Belahith M. Agreement between central and mixed venous oxygen saturation following cardiac surgery. J Anesth Clin Res 2014;5:386

18 el-Masry A, Mukhtar AM, el-Sherbeny AM, Fathy M, el-Meteini $M$. Comparison of central venous oxygen saturation and mixed venous oxygen saturation during liver transplantation. Anaesthesia 2009;64(4):378-382

19 Romagnoli S, Balsorano P, Landucci F, De Gaudio A. Mixed and central venous oxygen saturation are not interchangeable in patients with cardiogenic shock after cardiac surgery. Crit Care 2013;17(Suppl 2):180
20 Pérez AC, Eulmesekian PG, Minces PG, Schnitzler EJ. Adequate agreement between venous oxygen saturation in right atrium and pulmonary artery in critically ill children. Pediatr Crit Care Med 2009;10(1):76-79

21 Yazigi A, El Khoury C, Jebara S, Haddad F, Hayeck G, Sleilaty G. Comparison of central venous to mixed venous oxygen saturation in patients with low cardiac index and filling pressures after coronary artery surgery. J Cardiothorac Vasc Anesth 2008;22(1):77-83

22 Aggarwal NK, Kapoor PM, Kiran U, Chowdhury UK. Intraoperative central venous oxygen saturation as a surrogate marker for mixed venous oxygen saturation in patients undergoing cardiac surgery. J Anesth Clin Pharmacology 2007;23(1):29-33

23 Lorentzen AG, Lindskov C, Sloth E, Jakobsen CJ. Central venous oxygen saturation cannot replace mixed venous saturation in patients undergoing cardiac surgery. J Cardiothorac Vasc Anesth 2008;22(6):853-857

24 Redlin M, Koster A, Huebler M, et al. Regional differences in tissue oxygenation during cardiopulmonary bypass for correction of congenital heart disease in neonates and small infants: relevance of near-infrared spectroscopy. J Thorac Cardiovasc Surg 2008;136(4):962-967

25 Lee J, Wright F, Barber R, Stanley L. Central venous oxygen saturation in shock: a study in man. Anesthesiology 1972;36(5):472-478

26 Dahn MS, Lange MP, Jacobs LA. Central mixed and splanchnic venous oxygen saturation monitoring. Intensive Care Med 1988;14(4):373-378

27 Reinhart K, Rudolph T, Bredle DL, Hannemann L, Cain SM. Comparison of central-venous to mixed-venous oxygen saturation during changes in oxygen supply/demand. Chest 1989;95(6):1216-1221

28 Ramakrishna M, Hegde D, Kumaraswamy G, Gupta R, Girish T. Correlation of mixed venous and central venous oxygen saturation and its relation to cardiac index. Indian J Crit Care Med 2006;10(4):230-234 